\title{
ASIAN YEARBOOK OF INTERNATIONAL LAW
}

\author{
VOLUME 16 \\ 2010
}

FOUNDATION FOR THE DEVELOPMENT OF

INTERNATIONAL LAW IN ASIA

HANDONG INTERNATIONAL LAW SCHOOL 
First published 2013

by the Foundation for the Development of International Law in Asia (DILA) in collaboration with the Handong International Law School, South Korea.

c/o Handong International Law School

Handong Global University, Pohang, 791-708, Korea

(c) 2013 selection and editorial matter, the Foundation for the Development of International Law in Asia; individual chapters, the contributors.

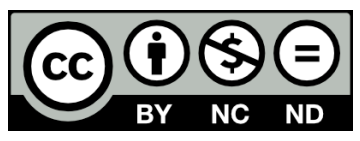

The Asian Yearbook of International Law, Vol 16 (2010) by the Foundation for the Development of International Law in

Asia and Handong International Law School, South Korea is licensed under a Creative Commons Attribution-NonCommercial-NoDerivs 3.0 Unported License. 


\title{
ASIAN YEARBOOK OF INTERNATIONAL LAW
}

\section{VOLUME 16 2010}

\author{
EDITOR-IN-CHIEF \\ Kevin Y.L. Tan \\ EXECUTIVE EDITOR \\ Hee Eun Lee
}

EDITORS

Javaid Rehman Sumaiya Khair

Associate Editor

Jeong Woo Kim

ASSISTANT EDITORS

Eun Joo Kim Tan Keum Lee

Yoonhee Lee In Ae Park

Megan Webb

STATE PRACTICE CONTRIBUTORS

Surendra Bhandari [Nepal] Camena Guneratne [Sri Lanka]

V.G. Hegde [India] Kanami Ishibashi [Japan]

Sumaiya Khair [Bangladesh] Javaid Rehman [Pakistan]

Eleni Polymenopoulou [Pakistan] Kevin Y.L. Tan [Singapore

Francis Tom Temprosa [Philippines] Atsushi Yoshii [Japan]

FOUNDING GENERAL EDITORS

Ko Swan Sik Christopher W Pinto J.J.G. Syatauw 


\title{
Foundation for the Development of International Law in Asia (DILA)
}

DILA was established in 1989, at a time when its prime movers believed that economic and political developments in Asia had reached the stage at which they would welcome and benefit substantially from a mechanism to promote and facilitate exchanges among their international law scholars that had failed to develop during the colonial era.

The Foundation was established to promote the study of: (a) and analysis of topics and issues in the field of international law, in particular from an Asian perspective; and (b) dissemination of knowledge of, international law in Asia; promotion of contacts and co-operation between persons and institutions actively dealing with questions of international law relating to Asia.

The Foundation is concerned with reporting and analyzing developments in the field of international law relating to the region, and not primarily with efforts to distinguish particular attitudes, policies or practices as predominately or essentially "Asian". If they are shown to exist, it would be an interesting by-product of the Foundation's essential function, which is to bring about an exchange of views in the expectation that the process would reveal areas of common interest and concern among the State of Asia, and even more importantly, demonstrate that those areas of interest and concern are, in fact, shared by the international community as a whole.

\author{
CHAIRMAN \\ Seokwoo Lee [South Korea] \\ VICE-CHAIR MEN
}

Nishii Masahiro

Hikmahanto Juwana

Bing Bing Jia

[Japan]

[Indonesia]

[China]

MEMBERS

\author{
Azmi Sharom [Malaysia] Surendra Bhandari [Nepal] \\ Kitti Jayangakala [Thailand] \\ Sumaiya Khair [Bangladesh] \\ Mario Gomez [Sri Lanka] \\ Hee Eun Lee [South Korea] \\ Javaid Rehman [Pakistan] \\ Seyed Jamal Seifi [Iran] \\ Maria Lourdes Sereno [Philippines] Kevin Y.L. Tan [Singapore]
}




\section{The Asian Yearbook of International Law}

Launched in 1991, the Asian Yearbook of International Law is a major internationally-refereed yearbook dedicated to international legal issues as seen primarily from an Asian perspective. It is published under the auspices of the Foundation for the Development of International Law (DILA) in collaboration with the Handong International Law School in South Korea. When it was launched, the Yearbook was the first publication of its kind, edited by a team of leading international law scholars from across Asia. It provides a forum for the publication of articles in the field of international law, and other Asian international legal topics.

The objects of the Yearbook are two-fold. First, to promote research, study and writing in the field of international law in Asia; and second, to provide an intellectual platform for the discussion and dissemination of Asian views and practices on contemporary international legal issues.

Each volume of the Yearbook contains articles and shorter notes, a section on State Practice, an overview of the Asian states' participation in multilateral treaties and succinct analysis of recent international legal developments in Asia, as well as book reviews. We believe this publication to be of importance and use to anyone working on international law and in Asian studies.

In keeping with DILA's commitment to encouraging scholarship in international law as well as in disseminating such scholarship, its Governing Board has decided to make the Yearbook open access from this volume (2010 volume 16) onwards. 
Kevin Y.L. Tan - 9789004379695 Downloaded from Brill.com๑4/26/2023 10:09:03AM via free access 


\section{TABLE OF CONTENTS}

Preface

\section{ARTICLES}

1. Hee Eun Lee \& Seokwoo Lee

Positivism in International Law: State Sovereignty,

Self-Determination and Alternative Perspectives

2. Fort Fu-Te liao

Partly Virtual, Partly Real: Taiwan's Unique Interaction with International Human Rights Instruments

3. Kevin YL Tan

International Law in the Courts of the Straits Settlements

4. Prabhakar Singh

Why Wield Constitutions to Arrest International Law

EDITORIAL NOTE

5. Javaid Rehman \& Eleni Polymenopoulou

Developments in Pakistan

LEGAL MATERIALS

6. Treaty Section - Karin Arts

155

7. State Practice of Asian Countries in INTERNATIONAL LAW

a. Courts \& Tribunals 189

b. Criminal Law 191

c. Diplomatic \& Consular 193

d. Economic Law 195

e. Environmental Law 199

f. Human Rights 207

e. International Humanitarian Law 285

f. International Organizations 288

g. International Law \& Municipal Law 290

h. Jurisdiction 305

i. Territory 313

$\begin{array}{ll}\text { j. Treaties } & 321\end{array}$ 


\section{LITERATURE}

\section{Book Reviews}

Javaid Rehman, International Human Rights Law, 2nd Edition by Sandrasegaram Paramalingam

Shirley V Scott, International LaW in World Politics:

An Introduction \&

Conway W Henderson, Understanding International LaW by Kevin YL Tan 


\section{PREFACE}

\section{Transitions}

The publication of this 16th volume of the Asian Yearbook of International Law, signals a new phase in the life of this venerable publication. Several transitions have occurred in the interim that have necessitated a reorganisation of the Yearbook's editorial team and mode of publication.

Between the publication of the last Yearbook and this, we have seen the retirement from the editorial committee of Professors Masahiro Miyoshi and Bhupinder Singh Chimni, untiring and indefatigable stalwarts of the Yearbook and of DILA. Both Professors Miyoshi and Chimni have been editors of the Yearbook since 1998 and have between them, racked up close to 30 years of service to the publication. We wish them both an enjoyable and productive retirement.

The old structure of the Yearbook's editorial committee - of having only three General Editors - was a legacy of DILA's history. At the time of its inception, the Yearbook had but three editors, and even after the change over of editors in 1998/1999, this structure was maintained. This placed a tremendous burden on the editors and often led to delays in the Yearbook's publication. In 2012, the structure of the Editorial Committee was revamped with two key objects: first, to bring more members onto the Committee; and second, to clear the backlog that has accumulated in the interim. Professor Javaid Rehman, who bravely stood up to the plate in 2009 after the resignation of Professor Li-ann Thio, helmed the Yearbook as Coordinating Editor till 2012, when I succeeded him as Editor-in-Chief.

\section{Collaborations}

Thanks to the very active leadership of Professor Seokwoo Lee, DILA has forged several important collaborations, most notably with the Korean Society of International Law, the Haesung Institute for Ethics in International Affairs, and the Northeast Asian History Foundation. Through these collaborations, DILA has managed to hold a small annual conference focused on themes like the history of international law in Asia, the law of the sea, territorial disputes and maritime delimitation. The Yearbook has thus profited indirectly from these collaborations in that several of 
the most important papers presented at these meetings were revised and published in its pages.

On 17 October 2012, as Editor-in-Chief of the Yearbook and representing DILA, I signed a Memorandum of Understanding with Dean Eric Enlow of the Handong International Law School under which Handong International Law School to work closely with DILA to publish the Yearbook, including assigning student editors to work on the Yearbook under the supervision of Professor Hee Eun Lee.

I am very pleased to report the great success of this collaboration. With additional hands on deck, we were able to get through the process of cite checking and copy-editing much more quickly and thoroughly than were able to do in the past, thanks to the hard work of the students from Handong. This Yearbook is the first fruit of that collaboration.

\section{Open Source and Free Electronic Distribution}

From the early 2000s, the Governing Board of DILA had expressed its concern about the distribution of the Yearbook. Collating the figures provided by the two publishers who published and distributed the Yearbook - Brill and Routledge - left us wondering if our publishing objective had been met. Circulation numbers were in the low hundreds, and the pricing of the Yearbook made it next to impossible for individual scholars or students to readily afford their own copies.

At the Governing Board meeting in Singapore in 2012, I proposed that we take the radical step of moving the journal onto an online platform and making it open source. It was already clear to many of us that the more widely circulated an article is, the more likely it is to have an impact on subsequent scholarship and accordingly, be cited. The quickest, cheapest and most efficient way of doing this is by making the Yearbook free as a portable document format (PDF) download.

The proposal was met with some skepticism and opposition. Some members felt that much prestige would be lost if we were no longer published by a reputable publisher, and most members of the Board felt that it was important that a physical copy of the Yearbook still be published. The palpability of holding a physical copy of a book or journal cannot be replaced. 
One major concern shared by everyone was the impression that might be created by having a publication made available for free. Would quality and standards suffer as a consequence?

Quality is uppermost in the minds of those who consider themselves serious scholars and at no time should this ever be compromised. Quality in journals and other publications is assured by a double-blind peer review process undertaken by like-minded scholars willing to give their time to review pieces sent to them. This is part and parcel of a scholar's life and has nothing to do with professional book production costs. Quality will thus not suffer so long as rigorous standards of review are adhered to. On our part, we have every intention to ensure that such rigorous standards of review continue to be part of our standard operating processes.

Free electronic distribution of the Yearbook will greatly enhance its reach and impact but this does not mean that hard copies will not be available to those who prefer such copies. With the great strides made in print-on-demand technology, readers of the Yearbook can choose to either download a PDF copy and print it out on their own printers, or click to Amazon.com and order a print copy which will be shipped to them just as any other traditionally-produced volume. Versions for mobile and portable devices like the iPad will also be made available in ePub format.

It is our fervent hope that these changes will allow the work of our contributors to be better served and that their work will reach a much larger audience, especially in the countries of Asia.

KeVIN YL TAN Editor-in-Chief 